\title{
Work Values, Emotional Intelligence, Work Environment and Career Commitment among Generation Y: A Proposed Framework
}

\author{
Nur Damayanti, Khulida Kirana Yahya *, Tan Fee Yean \\ School of Business Management, Universiti Utara Malaysia, 06010 UUM Sintok, Kedah, Malaysia
}

*Corresponding author: khulida@uum.edu.my

Article history: Received 25 February 2019 Received in revised form: 05 April 2019 Accepted: 28 May 2019 Published online: 29 August 2019

\begin{abstract}
This article reviews the relationship between work values, emotional intelligence, work environment and career commitment in the banking industry. In future, the banking industry will be dominated by the new workforce, millennial generation or Generation $\mathrm{Y}$, a generation whose behaviors and characteristics is different from the older generation before them. Generation $\mathrm{Y}$ is known as a very expressive generation, who as employees are confident but lacks career commitment and not interested in meticulous details; they present different views on work and duties. Generation Y, unlike employees of previous generations, tend to think that they have the competitive edge; no emotional connection or workplace loyalty. When job expectations are not met, they are more likely to switch jobs. The proposed study will be useful for all leaders and managers in the banking industry to gain a greater understanding of the work values of Generation Y employees. Consequently, this study may contribute useful knowledge in gaining career commitment among the Generation Y workforce.
\end{abstract}

Keywords: Career commitment; work values; emotional intelligence; work environment; generation Y

\begin{abstract}
Abstrak
Artikel ini mengkaji hubungan antara nilai kerja, kecerdasan emosi, persekitaran kerja, dan komitmen kerjaya dalam industri perbankan. Tenaga kerja industri perbankan di masa hadapan akan didominasi oleh generasi milenium atau Generasi Y yang mempunyai tingkah laku dan ciri-ciri yang berbeza dari generasi sebelumnya. Generasi Y dikenali sebagai generasi yang sangat ekspresif; sebagai pekerja, mereka berkeyakinan tinggi tetapi tidak mempunyai komitmen kerjaya dan tidak berminat dengan perkara metikulus; mereka mempunyai pandangan yang berbeza mengenai kerja dan tugas. Generasi Y, tidak seperti tenaga kerja terdahulu, cenderung untuk berfikir bahawa mereka mampu berdaya saing;tiada hubungan emosi atau kesetiaan kepada organisasi. Apabila jangkaan kerjaya mereka tidak dipenuhi, mereka akan menjurus kepada pekerjaan lain. Kajian yang dicadangkan adalah berguna untuk para pemimpin dan pengurus di dalam organisasi perbankan, menawarkan pemahaman yang lebih baik mengenai nilai kerja pekerja Generasi Y. Oleh itu, kajian ini menyumbang pengetahuan yang berguna bagi tujuan memperkasa komitmen kerjaya di kalangan Generasi Y.
\end{abstract}

Kata kunci: Komitmen kerjaya; nilai kerja; kecerdasan emosi; persekitaran kerja; generasi Y

(C) 2019 Penerbit UTM Press. All rights reserved

\subsection{INTRODUCTION}

The current workforce consists of three separate generations, namely the Baby Boomer generation (born between 1943 and 1960) the Generation X (born between 1961 and 1979), and most notably, the Generation Y (born from 1980 to 2000) (McCrindle, 2014) who is dominating the current labor market. Researchers (Kessler Berglund, Demler, Jin, Merikangas \& Walters, 2005; Twenge, Zhang \& Im, 2004; Wells \& Twenge, 2005; Twenge \& Campbell, 2008) posited that these generations are characterized in a number of different ways, namely personality character, behavior, psychological health, and attitude. The banking industry will be dominated by the new workforce, the Generation Y or millennials which has different behaviors and characteristics in comparison to previous ones. In the next few years, Gen Y will eventually be the new workforce replacing the previous generation. In addition, the retirement of aging workforce which resulted in talent crisis has indeed, been made within several studies; for instance, (Twenge, 2010; Hyuber, 2011; Cogin, 2012; Marais, 2013; Nizam, Ruzainy, Sarah \& Idayu, 2016; Queiri \& Dwikat, 2016) highlighted the rise of Generation Y in the global workforce.

Generation Y is generally labeled as individualistic; members of Generation Y like to express themselves, they want work autonomy, work identity and difficult tasks (Johnson, 2002). Generation Y refers to the generation of people born in the 1980s and because of different life experiences, they embrace different work values. This is in good agreement with Macky, Gardner and Forsyth, (2008), Krahn and Galambos (2014), Cogin (2012) who posited that Gen Y employees have work values, faith, personality traits and distinction in career attitudes as compared to other generations. Research in the Western world (Yankelovich, 1994; Van de Velde, Feiji \& Emmerik, 1988; Jurkiewicz \& Brown, 1998; Zuboff \& Maxmin, 2002) also confirmed the above contention. Twenge (2010) stated that the different 
experiences encountered by Generation $\mathrm{Y}$ will result in different expectations of work values and new preferences to the workplace. Empirical research on work values has found that work values predict job

Different work values between labor forces have been empirically observed by using longitudinal studies that isolate career impacts from generation effects (Twenge, Gentile, DeWall, Ma, Lacefield \& Schurtz, 2012). The differences in beliefs and work values of Generation $\mathrm{Y}$ employees can cause conflict in the work, miscommunication, misunderstanding, and thus reducing job satisfaction and employee productivity (Cennamo \& Gardner, 2008; Macky et al., 2008). Therefore, it is of vital importance to understand fully the value of work of Generation Y so that it will not cause conflict in the workplace among the generation. Additionally, work values were found to have a positive impact on career commitment of Generation Y academicians (Ching \& Kee, 2012).

Today, Generation Y has difficulty in determining career interests; they are often confused in choosing a career that suits their desires. This could be triggered by the feeling of being easily bored, wanting to try new things, will ultimately lead to dysfunctional emotions. Complex managerial work, such as demands and pressure from superiors as well as negative work environment will cause stress and unstable emotions. Emotional intelligence allows people to effectively manage their stress, thus avoiding its negative impacts on an individual's attitude (Goleman, 2006). Additionally, emotional intelligence has been found to be a predictor of human behavior (Mayer et al., 2000). It is the capability to understand and acknowledge feelings and the ability to assimilate emotions within the mind, feeling and reasoning with emotions, and managing emotions in oneself and others (Mayer et al., 2000). Generation $Y$ has emotional intelligence and is expected to be able to manage, acknowledge and use their emotions to get rid of these obstacles; people with higher emotional intelligence perform better than those with lower emotional intelligence (Carmeli, 2003).

Meister and Willyerd (2010) stated that Generation Y expects a strong and positive work environment; for instance, an environment that can stimulate brainstorming and induce innovative thinking to generate creative ideas. Generation Y seeks a pleasant work environment, a physical and social place that supports their work with the hope that the they are provided with opportunities to learn, socialize and work (Aruna \& Anitha, 2015). However, Jahn, Riphahn and Schnabel (2012) commented that organizations often face difficulties to find the right balance between building a work environment that is suitable for young employees and their senior counterparts, particularly who help them to maintain their knowledge and abilities. It is most challenging for senior employees to adapt in their work environment with their fellow juniors because senior employees present a very different work values and they consider young employees to be disloyal. Despite their reputation as a bunch of job hoppers, Generation Y can be the most loyal employees when they find organizations that best understand their desires. A comfortable and conducive work environment which facilitates the needs of employees is a source of employee motivation; for instance, employees are more committed to their work, not only they are motivated and but they are also satisfied with their work (Danish, Sidra \& Farid, 2013)

In line with the above statement, the biggest challenge that an organization might encounter with the Generation Y employees is what seems to be their lack of commitment (Kompas, 2017) because Generation Y employees have the tendency to change careers and it very difficult to make them stick with their career. If they feel that their expectations are not met, they will simply switch jobs; they are often influenced by shallowness, self-interest and narcissism (Merari \& Suyasa, 2015). In other words, attracting and retaining committed young workers, especially Generation Y has become the biggest challenge today. Therefore, organizations will need to consider having a human resource strategy in place, as means to improve employee's engagement and to recognize talents who are fluent with technologies, independent, optimistic, entrepreneurial, young and energetic (Huybers, 2011).

From the above explanation, Generation Y work values, emotional intelligence and work environment are likely to influence work commitment. The banking institutions need to compete against each other in order to provide conducive working environment; the need to fully understand the work values of Gen Y and to develop employee's emotional intelligence are all expected from each institution to minimize job hoping. Thus, the lack of work commitment in the banking industry needs great attention because an organization's success and competitiveness relies on its ability to develop its human resource, particularly the Generation Y. If an organization wants Generation Y to be committed to their work, the organization must understand their characters, desires, and needs. The organization also needs to change its conventional strategies, policies, and procedures to make it easier for them to keep their job.

The objective of this paper is to examine work values, emotional intelligence and work environment as antecedents of career commitment among Gen Y in the Indonesian banking industry.

\subsection{LITERATURE REVIEW}

\section{Career Commitment}

Career commitment is an individual's belief, feeling, and acceptance of organizational goals and values as dispositions to belong to the organization to strengthen their career advancement in the organization (Yahya \& Yean, 2015; Vandenberg \& Scarpello, 2004). Similarly, as stated by Costa et al. (2015), people are committed to their careers because of emotional feelings that resulted in strong identification with the profession, feeling motivated in their work because they felt they had chosen the right profession; while entrenched individuals continue to work for their needs or lack of alternatives.

Meanwhile, Mcketin, Livingston, Chalmers and Bright (2014) defined career commitment as the involvement and identification of individual professionals but consider that professional competence, as an important dimension in career commitment, However, Bakker, Demerouti, Oerlemans and Sonnentag (2013) considered career commitment as the intensity of individual work motivation in the chosen role. Similarly, Kadji-Beltran, Zachariou and Stevenson (2012) showed career commitment as individuals who identify and engage in selected work and development characteristics and involvement for career goals. An individual who is committed to their career tends to make more efforts to reach the objectives of their career. Herachwati and Rachma (2018) defined career commitment as an effective concept that is used to identify a series of related tasks in a particular field with behavior overcoming disappointment in an effort to pursue career objectives. 
Work Values

Work values are expressions of needs or goals sought by individuals to be achieved through financial and individual achievements of their professions (Kuron, Lyons, Schweitzer, \& $\mathrm{Ng}$, 2015). These values focus on what people need from work rather than the general results of the work itself (Twenge et al., 2010; Hauff \& Kirchner, 2015). Meanwhile, Kekesi and Agyemang (2014) defined work values as closely related to attitudes and behavior in the workplace and can be categorized into types of personal values. Work values are about increasing employment and helping to generate better involvement in the tasks assigned, which benefits companies to understand their employees well (Liao et al., 2012).

Furthermore, work values play a central role in career development and career choices (Choi et al., 2013). It has also been noted that conformity between work values and types of work can promote positive results of individuals and organizations, such as planning and recruitment of organizational labor, individual career decision-making, work choices and, adjustments (Wöhrmann, Fasbender \& Deller, 2016). The study by Ching and Kee (2012) found that work values affect the career commitment of Generation Y academics in Malaysia, as it indicates that academics prefer work values which are related to security and the environment.

\section{Emotional Intelligence}

Spano-Szekely, Griffin, Clavelle and Fitzpatrick, (2016) defined emotional intelligence (EI) as the capability of people to acknowledge their abilities and others, to distinguish between different feelings and labels correctly by using emotional information to guide their thinking and behavior. Emotional intelligence is important in a multigenerational workplace because employees who have emotional intelligence can control their emotions in resolving work conflicts and the demands of work. This can increase employee productivity so that it can create reciprocal relationships between employees and employers', employee happiness, job satisfaction, and increase career commitment and employee leadership skills towards an organization (Njoroge \& Yazdanifard, 2014). Meanwhile, Gayathri et al (2014) defined emotional intelligence as the ability to recognize emotions themselves, self-management to manage or regulate one's emotions, social awareness to understand other people's emotions or concern for others and relationship management to interact in developing, maintaining relationships and managing conflict.

The study by Chika and Emanuel (2014), revealed that emotional intelligence correlates with career commitment of bank employees. This development shows that for employees to enjoy their work and commit to it, they need to develop emotional intelligence competencies. Working in a bank requires a banker to have the ability to understand their customers' emotions, feelings, and sensitivities toward their verbal and nonverbal attitudes and behaviors. If this quality is lacking, bankers can often experience frustrating conflicts with their customers and this can negatively affect their commitment to their work. This makes a banker think of switching careers because they cannot stand the pressure to face customers. Thus, emotional intelligence has been found to be a predictor of human behavior (Chika \& Emanuel, 2014). This is the human ability to recognize their capabilities and that of others, to distinguish between different feelings and labels correctly and to use emotional information to guide their thinking and behavior (Spano-Szekely et al., 2016).

\section{Work Environment}

Mehboob and Bhutto (2012) defined work environment as a place in which individuals work. The physical, psychological and social aspects that characterize work conditions are a comprehensive work environment concept. Khuong and Le Vu (2014) showed that employees who are comfortable with their work environment tend to work more effectively and enjoy the work process as compared to those who feel uncomfortable in their work environment. Therefore, supervisors must improve the aspects of work environment to ensure the welfare of their employees.

According to Agbozo et al. (2017) an attractive and supportive work environment is very important for employee job satisfaction which will ultimately lead to employee performance and improvements in productivity. On the other hand, many organizations fail to achieve their goals because they fail to foster a positive and conducive work environment (Raziq \& Maulabakhsh, 2015). Similarly, Coopersmith (2017) explained that work environment impacts greatly on employees' productivity towards negative or positive results. Majority of employees spend more than $50 \%$ of their time at their workplace and this affects their mental health, abilities, and performance (Ogunyemi et al., 2015). Therefore, it is vital to provide the best possible workplace environment that allows employees to work in peace, keeping them focused; a good physical environment doesn't just affect e employee morale, but also improves their physical and emotional well-being, thus increases their performance and productivity.

Oludeyi (2013) found that work environment is a vital factor that influences career commitment among school teachers; they are committed to their careers because they enjoy working in a comfortable environment. Butt, Khan, Rasli and Iqbal (2012) also found that work environment had a positive impact on nurses' career commitment in hospitals. Onuka (2012) also stated that one of the factors that significantly influence career commitment is work environment, regardless of the work scope itself. Ali, Rehman, Ali, Yousaf and Zia (2010) found that employees are happy to come to work when their work environment is positive and comfortable; motivated employees can lead to increased productivity. Frequent and open communication is needed to make employees happy and productive (Akintanyo, 2010). Organizations that provide employee-friendly work environment promote good trust; employees feel that organizations care about them, a major factor closely related to career commitments. Hence, the positive effects of an organization's work environment can change employee's career commitment (Cicek, Sehitoglu \& Karaboga, 2016).

\subsection{THEORETICAL FRAMEWORK}

Work values, emotional intelligence, and work environment were chosen because these variables have strong impacts on the career commitment of Generation Y. This combination has yet been used to examine the career commitment of Generation Y employees, particularly in the Indonesian banking industry. This study proposes that work values, emotional intelligence and work environment have 
direct relationships with career commitment. Work values, emotional intelligence, and work environment are the independent variables while career commitment being the dependent variable. The objective of this study is to examine the influence of work values, emotional intelligence, and work environment on career commitment. This concept is further explained in Figure 1.

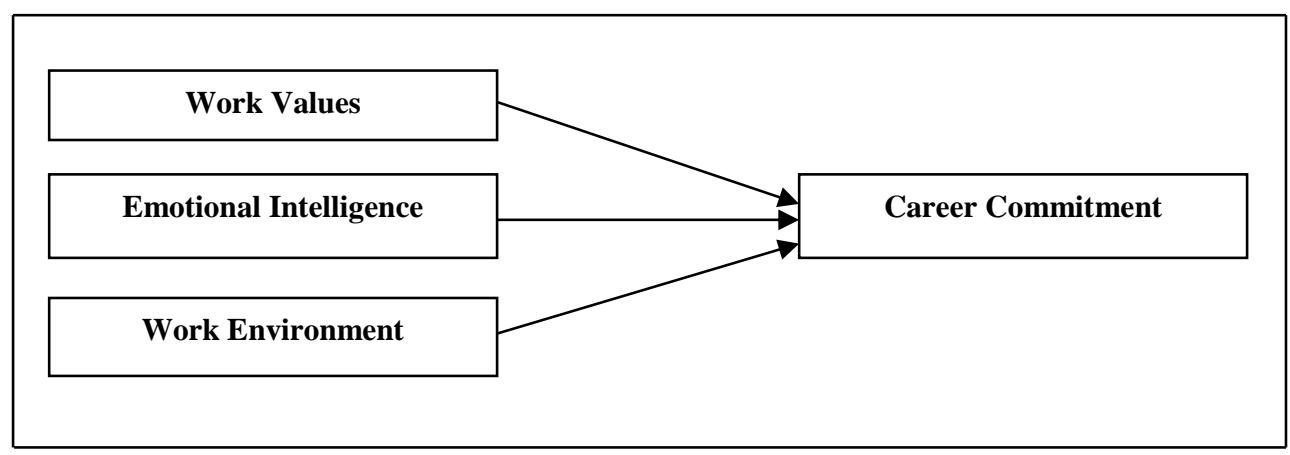

Figure 1 Research framework.

\subsection{METHODOLOGY}

This conceptual paper proposes the use quantitative research method through questionnaires, as an instrument, to collect data from respondents and to test the relationships between variables. The population for the study consists of Gen Y (born between 1980 and 2000 ) employees. The data will be analyzed using the SPSS (Statistical Package for the Social Sciences) version 25 software. This study will use four types of measurement scales to measure the independent variables (work values, emotional intelligence, and work environment) and the dependent variable (career commitment). This study will adopt the 17 items scale designed by Colarelli and Bishop (1990) to measure career commitment, 22 items scale designed by Elizur (1984) to measure work values, 16 items scale designed by Law, Wong and Song, (2004) to measure emotional intelligence, and 16 items scale designed by Broadfoot and Ashkanasy, (1994); Cammann, Fichman, Jenkins and Klesh, (1979); Smith, (1976) to measure work environment.

\subsection{CONCLUSION}

This conceptual paper proposes a framework to illustrate the relationships between work values, emotional intelligence, work environment and career commitment. The objective of this study is to examine the association of career commitment with work values, emotional intelligence, and work environment.

\section{References}

Agbozo, G. K., Owusu, I.S, Hoedoafia, M.A., \& Atakorah, Y.B. (2017). The Effect of Work Environment on Job Satisfaction: Evidence from the Banking Sector in Ahmed, N.O. (2017). Career Commitment: the Role of Self-Efficacy, Career Satisfaction and Organizational Commitment. World Journal of Entrepreneurship, Management and Sustainable Development, retrieved from https://doi.org/10.1108/ WJEMSD-06-2017-0038

Akintayo, D.I. (2010). Work-Family Role Conflict and Organizational Commitment Among Industrial Workers in Nigeria. Journal of Psychology and Counselling, $2(1), 1-8$.

Ali, I., Rehman, K., Ali, S.I., Yousaf, J., \& Zia, M. (2010). Corporate Social Responsibility Influences, Employee Commitment and Organizational Performance. African Journal of Business Management. 4(12), 2796- 2801.

Aruna, M., \& Anitha, J. (2015). Employee Retention Enablers: Generation Y Eemployees'. SCMS Journal of Indian Management, 12(3), 94-103.

Bakker, A.B., Demerouti, E, Oerlemans, W, Sonnentag, S. (2013). Workaholism and Daily Recovery: A Day Reconstruction Study Of Leisure Activities. Journal of Organizational Behavior, 34(1): 87-107.

Brenner, P (2004). Workers Physical Surrounding. Impact Bottom Line Accounting: Smarts Pros.com

Butt, H. S., Khan, F., Rasli, A. B. M., \& Iqbal, M. J. (2012). Impact of Work and Physical Environment on Hospital Nurses Commitment. International Journal Economic Resources, 3, 33-43.

Carmeli, A., Shalom, R., \& Weisberg, J. (2007). Considerations in Organizational Career Advancement: What Really Matters. Personnel Review, 36(2), 190-205.

Cennamo, L., \& Gardner, D. (2008). Generational Differences in Work Values, Outcomes and Person Organization Values Fit. Journal of Managerial Psychology, 23(8), 891-906. http://dx.doi.org/10.1108/02683940810904385

Chandrasekar, K. (2011). Workplace Environment and its Impact on Organizational Performance in Public Sector Organizations. International Journal of Enterprise Computing and Business Systems, 1(1), Retrieved from http://www.ijecbs.com/January2011/N4Jan2011.pdf

Chika, E., \& Emmanuel, O. O. (2014). Self-Efficacy, Emotional Intelligence, Achievement Motivation and Work- Value Orientation as Predictors of Career Commitment of Bank Workers in Imo State. Journal of Business and Management, 16(11), 55-62.

Ching, S. L., \& Kee, M., H. (2012). Work Values-Career Commitment Relationship of Generation Y Teachers in Malaysia. International Conference on Economics Marketing and Management, 242-246. Singapore: IACSIT Press. Retrieved from http://connection.ebscohost.com/c/articles/74385142/work-values-careercommitment-relationship-generation-y-Teachers-Malaysia

Choi, B. Y., Kim, B., Jang, S. H., Jung, S. H., Ahn, S. S., Lee, S. M., \& Gysbers, N. (2013). An Individual's Work Values in Career Development. Journal of Employment Counseling, 50(4), 154-165. http://dx.doi.org/10.1002/j.2161-1920.2013.00034.x

Cicek, I., Karaboga, T., \& Sehitoglu, Y. (2016). A New Antecedent of Career Commitment: Work to Family Positive Enhancement. Procedia - Social and Behavioral Sciences, 229, 417-426. 
Cogin, J. (2012). Are Generational Differences in Work Values Fact or Fiction? Multi-Country Evidence and Implications. The International Journal of Human Resource Management, 23(11), 2268-2294.

Coopersmith, J. (2017). The Principle of Virtual Work. Oxford Scholarship Online.

Costa, V., Balsan, L., Lima, M., Lopes, L., Santos, A., \& Tomazzoni, G., (2015). Levels of Career Commitment and Career Entrenchment of Nurses from Public and Private Hospitals.Revista Latino-Americana de Enfermagem, 23(6), 1033-1040.

Danish, R. Q., Sidra, R., \& Farid, A. (2013). Effect of Perceived Organizational Support and Work Environment on Organizational Commitment; Mediating Role of Self-Monitoring. Advances in Economic and Busines, 1(4), 312- 317.

Elizur, D., \& Koslowsky, M. (2001). Values and Organizational Commitment. International Journal of Manpower, 22(7), 593-9

Gayathiri, S., Gokulapriya, R., \& Arulmurugan, V. S. (2014). An Improved Channel Aware Smart Grid Transmission For MANET, International Journal of Innovations in Scientific and Engineering Research (IJISER), 1(4), 212-219. Ghana. Journal of Human Resource Management, 5(1), 12.

Goleman, D. (2006). Social Intelligence: The New Science of Human Relationships. New York: Bantam Books.

Goulet, L. R., \& Singh, P. (2002). Career commitment: A Reexamination and an Extension. Journal of Vocational Behavior, 61(1), 73-91.

Greenhaus, J. H., \& Callanan, G. A. (2006). Encyclopedia of Career Development (Eds). Thousand Oaks: Sage Publications.

Hall, R. (1968). Professionalism and Bureaucratization. American Sociological Review, 33, 92-104.

Hauff, S., \& Kirchner, S. (2015). Identifying Work Value Patterns: Cross-National Comparison and Historical Dynamics. International Journal of Manpower, 36(2), $151-168$.

Ho, C. C. (2006). A Study of the Relationships between Work Values, Job Involvement and Organisational Commitment among Taiwanese Nurses. Unpublished doctoral thesis, Queensland University of Technology, Australia.

Huybers, C. M. (2011). The Recruitment and Retention of Generation Y. 86.

Ismail, M., Rahim, A. N., Hou, L, K., \& Tahir, N. F. (2016). Cultural Values and Career Goal of Gen-X and Gen-Y Employees: Evidence from Selected Malaysia Companies. Organizations and Markets in Emerging Economies, 7(2), 43 - 64.

Jahn, E. J., Riphahn, R. T., \& Schnabel, (2012). Claus, Feature: Flexible Forms of Employment: Boon and Bane (August 2012). The Economic Journal, 122(562), F115F124. Available at SSRN: https://ssrn.com/abstract=2129006 or http://dx.doi.org/10.1111/j.1468-0297.2012.02532.x

Jain, R., \& Kaur, S. (2014). Impact of Work Environment on Job Satisfaction. International Journal of Scientific and Research Publications, 4 (1), 1-8.

Johnson (2002). Social Origins, Adolescent Experiences, and Work Value Trajectories during the Transition to Adulthood. Social Forces, 80, 1307-1341.

Jurkiewicz, C. L., \& Brown, R. G. (1998). Genxers Vs Boomers Vs Matures: Generational Comparison of Public Employee Motivation. Review of Public Personnel Administration, 18, 18-37.

Kadji-Beltran, C., Zachariou, A., \& Stevenson, R.B. (2012). Leading Sustainable Schools: Exploring the Role of Primary School Principals, Environmental Education Research, iFirst article: $1-21$.

Kalleberg, A., \& Berg, I. (1987). Work and Industry: Structures, Markets and Processes. New York: Plenum.

Kekesi, E. K., \& Agyemang, C.B. (2014). Perceived Job Insecurity and Psychological Distress: The Moderating Role of Work Values. International Journal of Management, Economics and Social Sciences, 3(1), 18-35.

Kessler, R. C., Berglund, P., Demler, O., Jin, R., Merikangas, K. R., \& Walters, E. E. (2005). Lifetime Prevalence and Age-of-Onset Distributions of DSM-IV Disorders in the National Comorbidity Survey Replication. Archives of General Psychiatry, 62, 593-602.

Khuong, M. N., \& Le Vu, P. (2014). Measuring the Effects of Drivers' Organizational Commitment Through the Mediation of Job Satisfaction: A Study in Ho Chi Minh City, Vietnam. International Journal of Current Research and Academic Review, 2 (2), 1-16.

Kompas, (2017). Retrieved February 12, 2017, from https://nasional.kompas.com/read/2017/02/11/17141441/generasi.y.doyan.pindahpindah.kerja.simak.kompas.minggu.12.2.2017.

Koslowsky, M., Weisberg, J., \& Yaniv, E. (2012). Ease of Movement and Sector Affiliation as Moderators of the Organizational and Career Commitment. Turnover Intention Link. International Journal of Manpower, 33(7) 822-839.

Krahn, H. J., \& Galambos, N. L. (2014). Work Values and Beliefs of 'Generation X' and 'Generation Y'. Journal of Youth Studies, 17(1), 92-112.

Kuron, L., Lyons, S., Schweitzer, L. \& Ng, E. (2015). Millennials Work Values: Differences Across the School to Work Transition. Personnel Review, 44(6), 991-1009.

Liao, C. W., Lu, C. Y., Huang, C. K., \& Chiang, T. L. (2012). Work Values, Work Attitude and Job Performance of Green Energy Industry Employees in Taiwan. African Journal of Business Management, 5299-5318.

Macky, K., Gardner, D., \& Forsyth, S. (2008). Generational Differences at Work: Introduction and Overview. Journal of Managerial Psychology, 28(8), 857-861. http://dx.doi.org/10.1108/02683940810904358

Marais, M. H. (2013). Retention and Engagement of Generation Y Engineers, (November), 171

Mayer, J. D., Salovey, P., \& Caruso, D. R. (2000). Models of Emotional Intelligence. In R. J. Sternberg (Ed.), Handbook of Intelligence, 396 - 420. Cambridge, England: Cambridge University Press.

McCrindle, M. (2014). The ABC of XYZ: Understanding the Global Generations. The ABC of XYZ: Understanding the Global Generations. Retrieved from http://mccrindle.com.au/resources/The-ABC-of-XYZ_Chapter-1.pdf

Mcketin, R., Livingston, M., Chalmers, J., \& Bright, D. (2014). The Role of off-license Outlets in Binge Drinking: A Survey of Drinking Practices Last Saturday Night among Young Adults in Australia. Drug and Alcohol Review, 33: 51-58.

Mehboob, F., \& Bhutto, N. A. (2012). Job satisfaction as a Predictor of Organizational Citizenship Behavior a Study of Faculty Members at Business Institutes. International Conference on Business, Economics. Management and Behavioral Sciences Papers, presented at Dubai, 7-8 January, 552-556.

Meister, J. C., \& Willyerd, K. (2010). Mentoring Millennials. Harvard Business Review, 88(5), 67-72.

Merari, L., \& Suyasa, I., K. (2015). Generasi Y, Generasi Z, dan Bonus Demografi Indonesia 2025. Retrieved from http://www.slideshare.net/leonardmerari/generasiygenerasi-Z-dan-bonus-demografi?from_action=save, pada tanggal 18 Juni 2016

Nizam, S., Ruzainy, M., Sarah, S., \& Idayu, N. (2016). Generation Y: Organizational Commitment and Turnover Intention. The European Proceedings Social and Behavioral Sciences, 21-23.

Njoroge, C. N. \& Yazdanifard, R. (2014). The Impact of Social and Emotional Intelligence on Employee Motivation in a Multigenerational Workplace. Global Journal of Management and Business Research: A Administration and Management, 14(3), 31- 36.

Ogunyemi, A. O., Akinlaja, S. O., Adesoye, E., Akindele-Oscar, A., Azeez, R. O., \& Omolade, M. A. (2015). Organisational Variables \& Effective Performance of Employees in Oil \& Gas Section: An Empirical Investigation. International Journal of Psychological Studies, 7(1).

Oludeyi, O. S. (2013). Classroom Design and Teachers' Performance in Selected Secondary Schools in Ogun State, Nigeria Redeemer's University. Journal of Management and Social Sciences, 1(2), 154-161.

Onuka C. A. (2012). Commitment in an Organization. Journal of Social Psychology, 4(5), 160-170.

PrincetonOne and Hobart, (2014). Understanding Generation Y. White Paper, Princeton One, 4-9.

Queiri, A., \& Dwaikat, N. (2016). Factors Affecting Generation Y Employees' Intention to Quit in Malaysian's Business Process Outsourcing Sector. Journal of Sustainable Development, 9(2), 78.

Raziq, A., \& Maulabakhsh, R. (2015). Impact of Working Environment on Job Satisfaction. Procedia Economics and Finance, 23, 717-725.

Spano-Szekely, M. T., Griffin, Q., Clavelle, J., \& Fitzpatrick, J. J. (2016). Emotional Intelligence and Transformational Leadership in Nurse Managers. Journal of Nursing Administration, 46(2), 101-108.

Thornton, A., \& Young-DeMarco, L. (2001). Four Decades of Trends in Attitudes Toward Family Issues in the United States: The 1960s Through the 1990s. Journal of Marriage and the Family, 63, 1009-1037.

Twenge, J. M. (2010). A Review of the Empirical Evidence on Generational Differences in Work Attitudes. Journal of Business and Psychology; Special Issue: Millennials and the World of Word, 25(2), 201-210. 
Twenge, J. M., Campbell, S. M., Hoffman, B. J., \& Lance, C. E. (2010). Generational Differences in Work Values: Leisure and Extrinsic Values Increasing, Social and Intrinsic Values Decreasing. Journal of Management, 36, 1117-1142.

Twenge, J. M., Gentile, B., DeWall, C. N., Ma, D. S., Lacefield, K., \& Schurtz, D. R. (2010). Birth Cohort Increases In Psychopathology Among Young Americans, 1938-2007: A Cross-Temporal Meta-Analysis of the MMPI. Clinical Psychology Review, 30, 145-154.

Van de Velde, E. G., Mandy, J., Feiji, A., \& Emmerik, H.V. (1998). Change in Work Values and Norms Among Dutch Young Adults: Ageing or Societal Trends. International Journal of Behavioral Development, 22, 55-76.

Vandenberg, R. J., \& Scarpello, V. (2004). A Longitudinal Assessment Of The Determinant Relationship Between Employee Commitments To The Occupation And The Organization. Journal of Organizational Behavior, 15(6), 535-47.

Wöhrmann, A. M., Fasbender, U., \& Deller, J. (2016). The Late Career: Using Work Values to Predict Post-Retirement Work Intentions. Career Development Quarterly, 64.

Yahya, K. K., \& Yean T. F. (2015). Enhancing career commitment: The influence of human resource management practices. International Journal of Business and Society, 16(2), 237-246.

Zuboff, \& Maxmin, J. (2002). The Support Economy: Why Corporations Are Failing Individuals and the Next Episode of Capitalism. New York: Viking, 24. 